\title{
SCHIZOPHRENIA SPECTRUM DISORDERS IN CHILDREN AND ADOLESCENTS: PREVALENCE AND DIAGNOSTICS
}

Pankova OF, Kazin NM, Ivanova SM $\bowtie$

Pirogov Russian National Research Medical University, Moscow, Russia

\begin{abstract}
The significance of studying the prevalence, age- and sex-related differences and diagnostic aspects of schizophrenia spectrum disorders (F2 Schizophrenia, schizotypal and delusional disorders) in pediatric and adolescent patients of mental health facilities is linked to the upcoming release of the International Classification of Diseases, Revision 11 (ICD-11). Its whole chapters have been updated, including disorders in the schizophrenia group. Diagnostic challenges posed by this debilitating group of mental disorders are associated with the diversity of clinical presentations, the incompleteness of psychopathological phenomena syndromes, and vague atypical symptoms. Changes in the prevalence of these disorders identified by the analysis of medical records at a mental health facility for children (a decline in the number of patients with F20, schizophrenia, and a surge in the number of patients with F21, schizotypal disorder) and significant disagreement about and disagreement about the diagnostic criteria for schizophrenia spectrum disorders in children and adolescents, evaluation of their dynamics, outcomes, and the social functioning of the patient necessitate further prospective follow-up studies aimed at overcoming the identified difficulties in the diagnosis, treatment and rehabilitation of such patients.
\end{abstract}

Keywords: ICD-10, children and adolescents, schizophrenia spectrum disorders, clinical forms, diagnosis, prognosis

Author contribution: Pankova OF conceived and designed the study, analyzed the obtained data, wrote and edited the manuscript; Kazin NM collected and analyzed the obtained data, wrote the manuscript; Ivanova SM analyzed the obtained data and wrote the manuscript.

$\triangle$ Correspondence should be addressed: Svetlana M. Ivanova

Ostrovityanova, 1, Moscow, 117997; lana.polanski@yandex.ru

Received: 31.03.2021 Accepted: 05.05.2021 Published online: 20.05.2021

DOI: 10.24075/brsmu.2021.022

\section{СОВРЕМЕННЫЕ ПРОБЛЕМЫ В ИЗУЧЕНИИ РАСПРОСТРАНЕННОСТИ И ДИАГНОСТИКЕ РАССТРОЙСТВ ШИЗОФРЕНИЧЕСКОГО СПЕКТРА У ДЕТЕЙ И ПОДРОСТКОВ}

\author{
О. Ф. Панкова, Н. М. Казин, С. М. Иванова $\bowtie$
}

Российский национальный исследовательский медицинский университет имени Н. И. Пирогова, Москва, Россия

\begin{abstract}
Актуальность изучения показателей распространенности, половозрастных особенностей и диагностики расстройств шизофренического спектра (раздел F2 Шизофрения, шизотипические и бредовые расстройства) у детей и подростков - пациентов детских психиатрических клиник объясняется предстоящим вступлением в действие Международной классификации болезней (МКБ-11), в которой существенные изменения внесены в целый ряд разделов, включая расстройства из группы шизофрении. Трудности диагностики данной группы инвалидизирующих расстройств связаны с полиморфизмом клинической картины, синдромальной незавершенностью психопатологических феноменов, наличием «стертых" атипичных форм. Выявленные при анализе стационарных карт пациентов одной из детских психиатрических больниц изменения в структуре заболеваемости (уменьшение числа пациентов с диагнозом шизофрении (F20) и значительное увеличение числа пациентов с диагнозом шизотипического расстройства (F21)), а также серьезные противоречия в вопросах диагностики, оценке динамики расстройств, исходов, уровня социального функционирования больных позволяют подчеркнуть необходимость дальнейшего изучения с использованием клинико-катамнестических методов для преодоления выявленных трудностей и противоречий в диагностике, лечении и реабилитации данных пациентов.
\end{abstract}

Ключевые слова: МКБ-10, дети и подростки, расстройства шизофренического спектра, распространенность, клинические формы, диагностика, прогноз Вклад авторов: О. Ф. Панкова — концепция и дизайн исследования, анализ полученных данных, подготовка текста, редактирование; Н. М. Казин - набор и обработка данных, написание статьи; С. М. Иванова - обработка данных, написание статьи.

$\triangle$ Для корреспонденции: Светлана Михайловна Иванова ул. Островитянова, д. 1, г. Москва, 117997; lana.polanski@yandex.ru

Статья получена: 31.03.2021 Статья принята к печати: 05.05.2021 Опубликована онлайн: 20.05.2021

DOI: $10.24075 /$ vrgmu.2021.022

According to statistics, the detection rate of mental disorders, including psychotic spectrum disorders, in the Russian population is declining [1]. At the same time, a Russian study conducted in 2000-2018 has revealed a rise in psychotic disorders among children and a high prevalence of mental illness among teenagers and children, compared to adults, amid a decline in the child and adolescent population [2].

\section{Schizophrenia spectrum disorders in children and adolescents}

The significance of studying schizophrenia spectrum disorders, which comprise a group of debilitating conditions, stems from the high frequency of their manifestation, diversity of clinical presentation, the incompleteness of psychopathological phenomena syndromes, and the occurrence of atypical forms with vague symptoms [3-5]. Such clinical diversity results in the insufficient understanding of the essence and the prognostic role of these conditions, complicating the differentiation between their clinical forms. Diagnostic approaches to schizophrenia vary between countries; being diagnosed with schizophrenia and receiving treatment for this disease has a profound impact on one's mental health and future. In Europe and America, it is advisable to avoid the diagnosis of schizophrenia in children younger than 8-14 years. By contrast, schizophrenia and schizophrenia spectrum disorders are acceptable labels in Russia. The Russian version of ICD-10 has a separate entry for "childhood schizophrenia" under the F20.8 (other schizophrenia) category. The diagnostic aspects of schizophrenia spectrum disorders are demanding special attention in light of the upcoming ICD-11, as the clinical diagnostic paradigm will be shifting from the categorical to 
the dimensional principle $[6,7]$. Timely diagnosis is no less important than an accurate definition. Multiple foreign and some Russian publications provide evidence that early treatment at the prodromal stage can significantly reduce the risk of the first psychotic episode, improve the long-term outcome, maintain social drive and the high level of the patient's functioning [810]. These data underscore the importance of further research into the prevalence, diagnostic challenges and treatment of schizophrenia spectrum disorders.

Recent epidemiological data on schizophrenia spectrum disorders among children and adolescents are very scarce. There are a few publications on the prevalence of the major mental disorders, including schizophrenia spectrum disorders, among children and adolescents in the past 15 years $[11,12]$.

The analysis of medical records of patients undergoing medical examination and treatment at G. E. Sukhareva Research and Practical Center for Mental Health of Children and Adolescents in 1999-2019 allowed us to identify the main diagnostic challenges and problems of studying the prevalence of schizophrenia and schizophrenia spectrum disorders (F2) in children and adolescents since the adoption of ICD-10 in Russia. Throughout the specified period, the prevalence of F2 disorders remained stable ( \pm standard deviation, SD) at $10.12 \pm 1.61$. There was an insignificant increase in prevalence (both in relative and absolute values) during the past two years included in the analysis, which coincided with a rise in hospitalizations and probably reflected a growing trend in the prevalence of mental illness in children and adolescents.

\section{Prevalence of schizophrenia spectrum disorders}

Fig. 1 shows cumulative data for the entire analyzed period and data for the first and last years of our study. The following schizophrenia spectrum disorders prevailed among children and adolescents: schizophrenia (F20), schizotypal disorder (F21), acute and transient psychotic disorders (F23), and schizoaffective disorder (F25). Together, these conditions accounted for $99.6 \%$ of all mental illnesses in the studied cohort and formed the core of the spectrum.

Of all the patients with F2, 48.8\% had schizophrenia, about one-third (32.3\%) had schizotypal disorder, $11.7 \%$ had schizoaffective disorder, and $6.8 \%$ had transient psychotic disorder. Importantly, when ICD-10 was first introduced in 1999, schizophrenic patients made up $75.3 \%$ of all F2 patients. By 2019, the proportion of schizophrenic patients had decreased 3 -fold, accounting for $25.8 \%$ of patients in the F2 group. By contrast, the number of patients diagnosed with schizotypal disorder had increased dramatically (6-fold
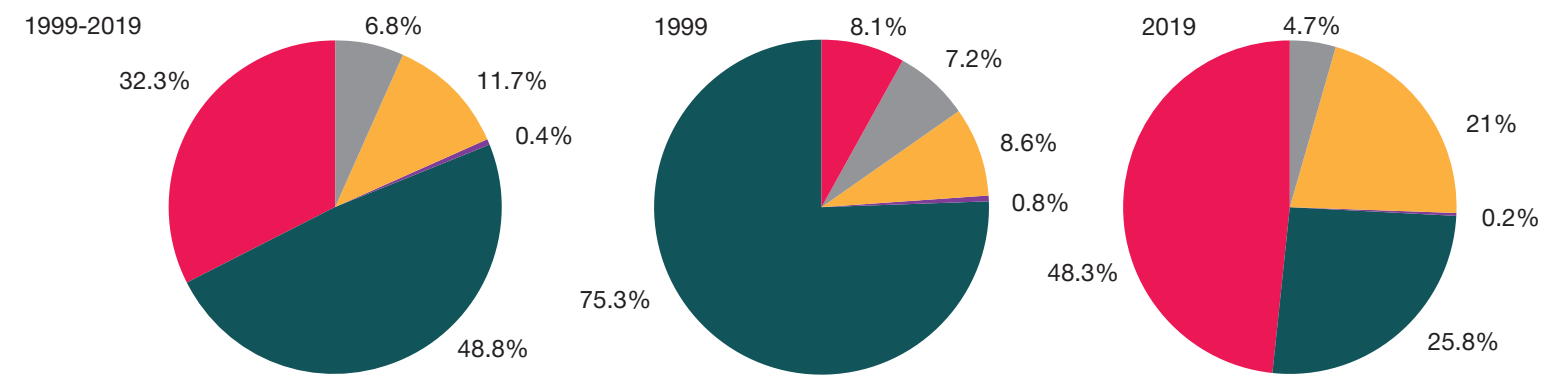

$\mathrm{F} 20(n=3403)$

F21 $(n=2249)$

$\mathrm{F} 23(n=473)$

$\mathrm{F} 25(n=818)$

Other schizophrenia spectrum disorders $(n=32)$$$
\text { F20 }(n=177)
$$$$
\mathrm{F} 21(n=19)
$$$$
\text { F23 }(n=17)
$$$$
\mathrm{F} 25(n=20)
$$$$
\mathrm{F} 20(n=193)
$$$$
\mathrm{F} 21(n=361)
$$$$
\text { spectrum disorders }(n=2)
$$$$
\mathrm{F} 23(n=35)
$$$$
\mathrm{F} 25(n=157)
$$

percentagewise and 19-fold in absolute values). The number with schizoaffective disorder had increased almost stable.

me majority of the patients were 11-14 years old, except patients with schizoaffective disorder, who were 15-17 dex ohrenia, schizotypal and schizoaffective disorders. Sex psychosis: $53.1 \%$ were males and $46.9 \%$ were females.

\section{Prevalence dynamics of schizophrenia and schizophrenia}

Fig. 2 shows that F20 and F21 curves behave differently. There is a gradual decline in schizophrenia prevalence, slowing a little in 2013, and a rise in the number of patients with schizotypal surge in 2017-2019. The level of confidence for the frequency

Trends in prevalence and diagnostic problems associated with schizophrenia spectrum disorders in children and adolescents

a prevalence of

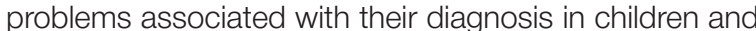
( (F) number of patients with schizophrenia (F20) and a ef this subgroup, $71.2 \%$ were diagnosed with F21.8 schizotypal doneurotic schizophrenia, and $15.2 \%$ were diagnosed were diagnosed with pseudoneurotic schizophrenia (iagnosed with pseudopsychopathic diagnosis of F21-F29 was established before schizophrenia was verified.

our opinion, the term "schizotypal personality disorder" 21.8) is incorrect because personality disorder cannot be diagnosed in children and adolescents; but it is legitimate to say that their schizoid traits are progressing. The criteria for

Fig. 1. Prevalence of schizophrenia spectrum disorders 


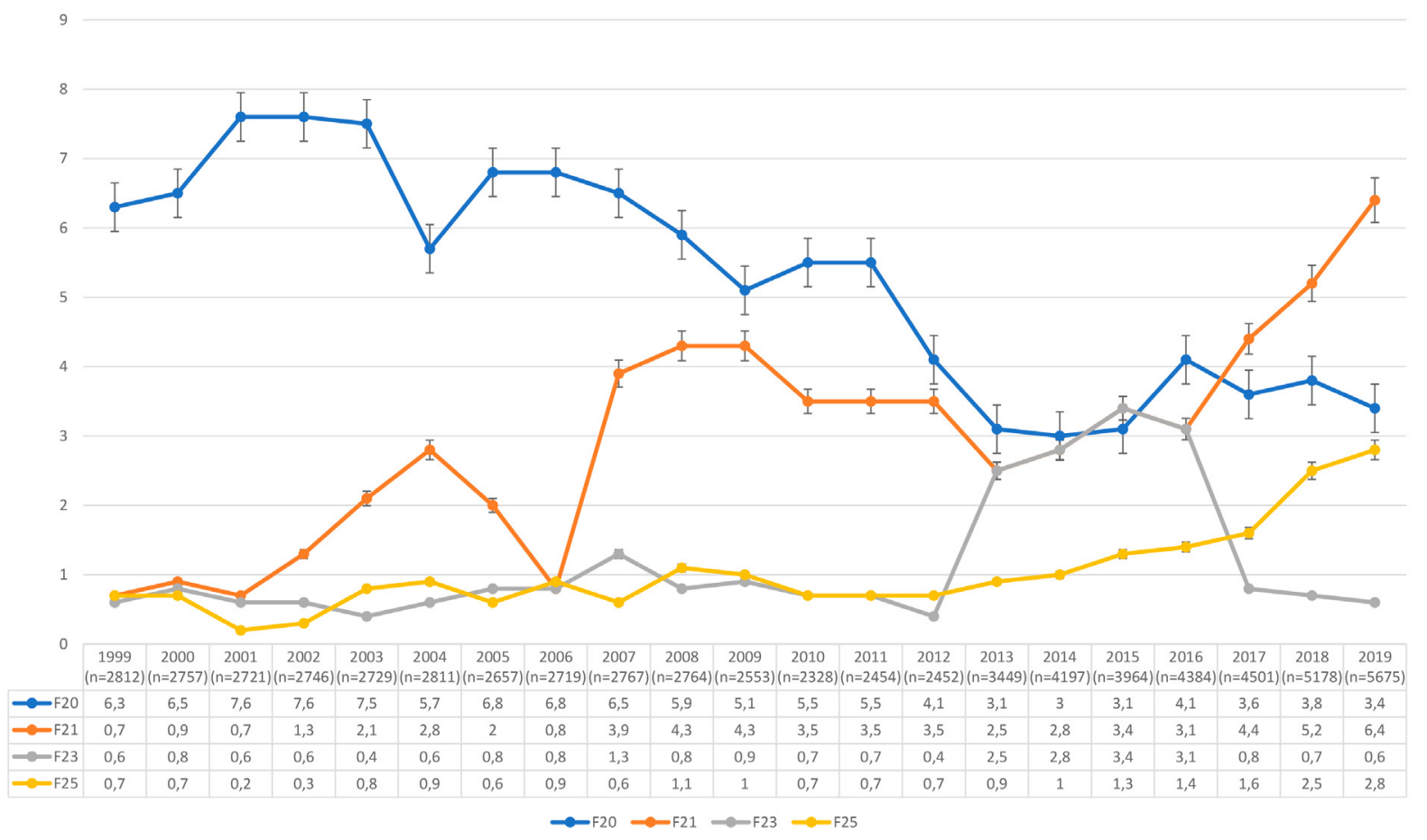

Fig. 2. Prevalence dynamics of schizophrenia and major schizophrenia spectrum disorders relative to the total number of hospitalized patients

the diagnosis of schizotypal personality disorder in children and adolescents do not include character traits; instead, they are based on the symptoms specified in the preamble of the Russian Thesaurus of Psychiatry, which is used to classify mental disorders. The preliminary analysis of medical records revealed that the reported clinical presentations did not meet the criteria for schizotypal disorder in many cases; however, in all age groups the number of patients diagnosed with schizotypal personality disorder (F21.8) increased at discharge.

In our opinion, this diagnostic transformation can be explained by social factors and stigma, which significantly affect clinical decision-making and force the clinician to come up with a diagnosis that would allow the patient to integrate into society. The stigma of schizophrenia has been widely discussed in Russian and foreign publications [14, 15]. Patients and their parents fear being stigmatized. This fear is not irrational because a grave psychiatric diagnosis can reduce career opportunities and chances to marry. Due to fear, patients delay a visit to public or private psychiatrists, psychologists, neurologists, etc. This prevents them from receiving timely health care, which, among other things, includes social and pedagogical interventions, psychotherapy and other types of rehabilitation.

\section{Conclusion}

The main candidate explanations of the identified diagnostics problems are a) changes in the clinical presentation of the disease, such as the growing prevalence of non-psychotic forms of schizophrenia spectrum disorders, including attenuated and quasi-psychosis (this is partly supported by the relatively stable number of patients with transient psychosis (F23) and schizoaffective disorder (F25)); b) vague yet diverse symptoms at the prodromal stage before the onset of psychotic symptoms in children and teenagers, a dissociation between the severity of the condition and social functioning, insufficient clarity of diagnostic criteria; c) the stigma of schizophrenia and the tendency to mitigate it be establishing a more socially acceptable diagnosis. The identified difficulties and disagreement about the diagnostic criteria for schizophrenia spectrum disorders in children and adolescents, evaluation of their dynamics, outcomes, and the social functioning of the patient necessitate further prospective follow-up studies.

\section{References}

1. Kekelidze ZI, Kazakovcev BA, redaktory. Jepidemiologicheskie pokazateli i pokazateli dejatel'nosti psihiatricheskih sluzhb v Rossijskoj Federacii (2005-2013 gg.). M., 2015; 572 s. Russian.

2. Makushkin EV, Demcheva NK. Dinamika i sravnitel'ny] analiz detskoj i podrostkovoj zabolevaemosti psihicheskimi rasstrojstvami v Rossijskoj Federacii v 2000-2018 godah. Rossijskij psihiatricheskij zhurnal. 2019, 4: 4-15. Russian.

3. Mazaeva NA. Podrostkovyj vozrast i shizofrenija. Psihiatrija. 2008; 2: 16-28. Russian.

4. Makarov IV. Psihiatrija detskogo vozrasta. Rukovodstvo dlja vrachej. Sankt-Peterburg: Nauka i tehnika, 2019; 992 s. Russian.

5. Parnas J. The core Gestalt of schizophrenia. World Psychiatry. 2012; 11 (2): 67.

6. Gaebel W, Jessen F, Kanba S. Neurocognitive disorders in ICD-11: the debate and its outcome. World Psychiatry. 2018; 17 (2): 229-30.

7. Kotov R, Krueger RF, Watson D. A paradigm shift in psychiatric classification: the Hierarchical Taxonomy Of Psychopathology (HiTOP). World Psychiatry. 2018; 17 (1): 24-25.

8. Omelchenko MA, Golubev SA, Nikiforova IYu, Kaleda VG. Risk manifestacii jendogennyh psihozov u bol'nyh s nepsihoticheskimi psihicheskimi rasstrojstvami junosheskogo vozrasta. Zhurnal nevrologii i psihiatrii im. S.S. Korsakova. 2014; 114 (6): 14-20. Russian. 9. Fusar-Poli P, Salazar de Pablo G, Correll CU, Meyer-Lindenberg A, 
et al. Prevention of Psychosis: Advances in Detection, Prognosis, and Intervention. JAMA Psychiatry. 2020; 77 (7): 755-65.

10. Stafford MR, Jackson H, Mayo-Wilson E, et al. Early interventions to prevent psychosis: systematic review and meta-analysis. BMJ. 2013; 346: f762. DOI: 10.1136/bmj.f185.

11. Pankova OF, Usacheva EL, Abramov AV, Danilova MY, Dorina IV, Smirnov II, Svintsova AV. Organizational issues relating to the inpatient psychiatric care of children and adolescents in the context of current trends. International Journal of Culture and Mental Health. 2018; 11 (1): 75-86,

12. Pankova OF, Radionov DS, Ivanova SM, Dorina IV. Shizofrenija i rasstrojstva shizofrenicheskogo spektra $v$ klinike sovremennoj detskoj psihiatrii (analiz gospitalizacij $\vee$ krupnejshuju

\section{Литература}

1. Кекелидзе 3. И., Казаковцев Б. А., редакторы. Эпидемиологические показатели и показатели деятельности психиатрических служб в Российской Федерации (2005-2013 гг.). М., 2015; 572 с.

2. Макушкин Е. В., Демчева Н. К. Динамика и сравнительный анализ детской и подростковой заболеваемости психическими расстройствами в Российской Федерации в 2000-2018 годах. Российский психиатрический журнал. 2019, 4: 4-15.

3. Мазаева Н. А. Подростковый возраст и шизофрения. Психиатрия. 2008; 2: 16-28.

4. Макаров И. В. Психиатрия детского возраста. Руководство для врачей. Санкт-Петербург: Наука и техника, 2019; 992 с.

5. Parnas J. The core Gestalt of schizophrenia. World Psychiatry. 2012; 11 (2): 67.

6. Gaebel W, Jessen F, Kanba S. Neurocognitive disorders in ICD11: the debate and its outcome. World Psychiatry. 2018; 17 (2): 229-30.

7. Kotov R, Krueger RF, Watson D. A paradigm shift in psychiatric classification: the Hierarchical Taxonomy Of Psychopathology (HiTOP). World Psychiatry. 2018; 17 (1): 24-25.

8. Омельченко М. А., Голубев С. А., Никифорова И. Ю., Каледа В. Г. Риск манифестации эндогенных психозов у больных с непсихотическими психическими расстройствами юношеского возраста. Журнал неврологии и психиатрии им. С.C. Корсакова. 2014; 114 (6): 14-20.

9. Fusar-Poli P, Salazar de Pablo G, Correll CU, Meyer-Lindenberg A, et al. Prevention of Psychosis: Advances in Detection, Prognosis, psihiatricheskuju kliniku Moskvy). Voprosy psihicheskogo zdorov'ja detej i podrostkov. 2019; 19 (4): 47-56. Russian.

13. Kostyuk GP, Shmukler AB, Golubev SA. Jepidemiologicheskie aspekty diagnostiki shizofrenii v Moskve. Social'naja i klinicheskaja psihiatrija. 2017; 27 (3): 5-9. Russian.

14. Yastrebov VS, Mihaylova II, Gonzhal OA, Trushhelev SA. Faktory stigmatizacii lic s psihicheskimi rasstroi-stvami: metodicheskie rekomendacii. M.: Izd-vo ZAO Justicinform, 200; 22 s. Russian.

15. Sibitz I, Amering M, Unger A, Seyringer ME, Bachmann A, Schrank B, et al. The impact of the social network, stigma and empowerment on the quality of life in patients with schizophrenia. Eur Psychiatry. 2011; 26: 28-33. DOI: https://doi. org/10.1016/j. eurpsy.2010.08.010.

and Intervention. JAMA Psychiatry. 2020; 77 (7): 755-65.

10. Stafford MR, Jackson H, Mayo-Wilson E, et al. Early interventions to prevent psychosis: systematic review and meta-analysis. BMJ. 2013; 346: f762. DOI: 10.1136/bmj.f185.

11. Pankova OF, Usacheva EL, Abramov AV, Danilova MY, Dorina IV, Smirnov II, Svintsova AV. Organizational issues relating to the inpatient psychiatric care of children and adolescents in the context of current trends. International Journal of Culture and Mental Health. 2018; 11 (1): 75-86,

12. Панкова О. Ф., Радионов Д. С., Иванова С. М., Дорина И. В. Шизофрения и расстройства шизофренического спектра в клинике современной детской психиатрии (анализ госпитализаций в крупнейшую психиатрическую клинику Москвы). Вопросы психического здоровья детей и подростков. 2019; 19 (4): 47-56.

13. КостюкГ.П., Шмуклер А. Б, Голубев С. А.Эпидемиологические аспекты диагностики шизофрении в Москве. Социальная и клиническая психиатрия. 2017; 27 (3): 5-9.

14. Ястребов В. С., Михайлова И. И., Гонжал О. А., Трущелёв С. А. Факторы стигматизации лиц с психическими расстройствами: методические рекомендации. М.: Изд-во ЗАО Юстицинформ, 200; 22 c.

15. Sibitz I, Amering M, Unger A, Seyringer ME, Bachmann A, Schrank B, et al. The impact of the social network, stigma and empowerment on the quality of life in patients with schizophrenia. Eur Psychiatry. 2011; 26: 28-33. DOI: https://doi. org/10.1016/j. eurpsy.2010.08.010. 